\title{
IPARD FUNDS IN THE FUNCTION OF THE DEVELOPMENT OF THE RURAL AREAS OF THE REPUBLIC OF SERBIA
}

\author{
Stanislav Zekic*, Bojan Matkovski and Zana Kleut \\ Faculty of Economics, University of Novi Sad, Subotica, The Republic of Serbia
}

By acquiring the conditions for the usage of the pre-accession funds of the European Union, concretely the instrument for rural development (Instrument for Pre-accession Assistance in Rural Development - IPARD), The Republic of Serbia (RS) will have a chance to improve the position of its agricultural farms and the conditions of its rural areas. Agriculture is specifically important for the economy in RS, and the rural population makes up almost one-half of the population, which additionally enlarges an interest in these funds. In addition, the objective of the research is to identify the effects of the usage of the IPARD funds on the development of the rural areas, respectively the socio-economic progress of the rural population. A qualitative descriptive analysis on the basis of the empirical data was used. The basic conclusions are that, thus, structured funds will have a limited impact on the reduction in the development inequalities and the achievement of the parity living conditions between the rural and the urban areas. Namely, the dominant focus of the IPARD funds on the investments in agricultural farms and enterprises, and not in rural households, limits the level of their impact on the rural development in RS.

Keywords: rural development, IPARD funds, agriculture, the Republic of Serbia, the European Union

JEL Classification: C44, C61, G11

\section{INTRODUCTION}

Since 2016, a possibility of using the EU pre-accession funds, i.e. the fifth Instrument for Pre-accession Assistance (IPA) component - the Instrument for Preaccession Assistance in Rural Development (IPARD) - should be opened for the Republic of Serbia (RS). Thus, as a candidate for the EU membership, RS is for the first time in the position to use the EU funds for

\footnotetext{
* Correspondence to: S. Zekic, Faculty of Economics in Subotica, University of Novi Sad, Segedinski put 9-11, 24000 Subotica, The Republic of Serbia; e-mail: zekics@ef.uns.ac.rs
}

agriculture and rural development to a larger extent. The importance of accession to these funds is the consequence of the relative significance of agriculture in the overall economy, and of the rural areas in Serbia's society. The production performances of agriculture and the agro-industry are not at an adequate level (Gajić \& Zekić, 2013), and the slower development of the rural areas in comparison to the urban ones, as well as the poverty which is the dominant rural phenomenon, is present (Bogdanov, 2007). Unfavorable demographic tendencies, the poorer educational structure, the lack of the infrastructure and the inadequate service sector 
are at the same time the basic characteristics of the rural areas and the main reason for their inadequate position (Zekić, Matkovski, 2015). It is uncertain to which extent this form of external support can contribute to the resolution of the essential problems of the rural population, the problems practically present since the establishment of the modern Serbian state (Čalić, 2004).

Serbia's rural development policy concentrates on an increase in the competitiveness of the rural economy, the improvement of the life quality of the rural population, as well as on the protection of the agro-environment. However, the funds intended for the achievement of these aims are relatively low (Matkovski, Kleut, 2014). This policy relies on the development funds encouraging investments in the rural and the undeveloped areas, and the cooperation of institutions at the regional and the local levels is necessary in order to work as a unique vertical system (Lovre, 2013).

The research subject in the paper is the connectivity between the available IPARD funds and the rural development of RS, figured as an improvement of the life quality of the rural population, i.e. a reduction in the unfavorable socio-economic tendencies in the rural areas. The impact of the stated funds on the agro-food sector is only researched in to the extent to which it influences the level of rural development, since agriculture, although dominant in Serbia's rural areas, still cannot be the only one trigger of the rural areas development. According to that, the main aim of this research is the estimation of the potential effects of the usage of these funds in the Serbian rural development.

In accordance with the stated subject and objective of the research, the paper starts from the following hypotheses:

H1: The EU's Pre-accession Funds aimed at agriculture and rural development will have a limited impact on the rural development of the Republic of Serbia in terms of the improvement of the life quality of the rural population.

H2: The IPARD funds' dominant orientation towards capital investments in Serbia's agriculture will not significantly reduce the economic lagging of the rural areas in comparison to the urban ones.

In order to test the listed hypotheses, a qualitative methodology based on the empirical data and a descriptive analysis is used, and the starting point of the research is the analysis of the conditions in the rural areas of RS. Then, the structure of the IPARD funds' support is analyzed, and the possibilities and limitations of the impact of these funds on the development of the rural areas of RS are identified.

\section{THE SPECIFICITIES OF THE RURAL AREAS OF THE REPUBLIC OF SERBIA}

The rural areas, as well as agricultural production, have specific importance for the Serbian overall economy. Namely, depending on the applied methodology, the rural areas cover $75-90 \%$ of the territory of RS, where about $40-50 \%$ of the population is inhabited1. The primary sector employs about $20 \%$ of the economically active population, and produces about $10 \%$ of the Gross Domestic Product (GDP) (MAEP, 2014). The significance of agriculture in the Serbian overall economy is the result of the favorable agro-ecological conditions and the insufficiently developed overall economy. As in the case of the majority of other countries, the Serbian rural areas show the signs of a socio-economic lagging behind the urban areas. The rural areas in RS are faced with the process of aging, impoverishment and discharging, as a consequence of the migration movements towards cities, primarily by the most skillful and the most vital part of the population (Komazec \& Aleksic, 2015). One of the most evident problems is the unfavorable demographic tendencies as the consequence of the decades long lagging, on the one hand, whereas they represent a part of the unfavorable overall demographic tendencies of $\mathrm{RS}$, on the other. In other words, they are the result of the low birthrate and the migrations to both cities and foreign countries. According to that, the population in the rural areas is twice as high in comparison to the decreasing urban population2, which is most obvious in the regions of Southern and Eastern Serbia3 (Statistical Office of the Republic of Serbia - Republički zavod za statistiku, 2011). Beside the decrease in the 
population, the unfavorable age structure of the population is present as well. Namely, the average age of the rural population is about $43-44$ years, and every fifth rural inhabitant is older than 65 years of age. In the region of Southern and Eastern Serbia, the situation is even worse, since the average age there is 45.7, whereas a quarter of the population is older than 65 years of age (MPZŽS RS, 2014). In order to motivate young people to stay and live and work in the rural areas, it is necessary to increase the attractiveness of these areas for investment (Ristic, 2013).

Unfavorable tendencies are present in the educational structure as well, especially in comparison to the urban population. A large number of rural inhabitants have only primary education, the largest number of them are with secondary education, whereas only a small number of them have higher education. The Belgrade region is above the average level and in Autonomus Province of Vojvodina (A. P. Vojvodina), the situation is slightly more favorable. The educational structure is the most unfavorable in the region of Southern and Eastern Serbia, where $58 \%$ of the population has no more than primary education, and half of them have not finished elementary school. The situation is not much better in the region of Šmadija and Western Serbia, which is the Serbian most rural region (Table 1). The listed tendencies are especially characteristic of the female rural population, in whose case one-third did not attend any school and more than one-half have no qualifications (MPZŽS RS, 2014).

The stated educational and age structure of the population presents the largest obstacle for the development of the rural areas; respectively, it negatively impacts the process of agricultural modernization and especially the process of the development of the non-agricultural sector. This is particularly characteristic of rural areas to the south of Belgrade, where small semi-subsistent farms with highly extensive agricultural production and extremely modest possibilities for employment outside agriculture are dominant. The situation is somehow more favorable in the region of Sumadija and Western Serbia, where there are a lot of farms that have additional sources of income, and this region is the leading one in the development of rural tourism in comparison to the other rural areas of RS. Moreover, the infrastructural equipment is at a higher level in comparison to the region of Southern and Eastern Serbia, where there are significant infrastructural limitations. In this region, rural poverty is the most prominent, which is primarily the consequence of the negative tendencies in the most of socio-economic characteristics (Zekić, Matkovski, 2015).

The situation is more favorable in the case of the Belgrade region and the region of the A. P. of Vojvodina. The advantages of the A. P. of Vojvodina are reflected in its natural benefits, as well as in the specific characteristics of historical development, which has enabled better infrastructural supply and the more developed service sector. Also, the development of agricultural production, as the dominant activity of the rural areas, is at a much higher level, and agricultural farms are largely sustainable. On the other hand, due to the powerful economic influence of the large urban area, the Belgrade region is atypical in comparison

Table 1 The rural population and the educational structure of the Republic of Serbia

\begin{tabular}{|c|c|c|c|c|c|}
\hline & \multicolumn{2}{|l|}{$\begin{array}{l}\text { The rural } \\
\text { population }\end{array}$} & \multicolumn{3}{|c|}{$\begin{array}{l}\text { The educational structure } \\
\text { of the rural population (\%) }\end{array}$} \\
\hline & $\begin{array}{l}\bar{\pi} \\
\stackrel{0}{0} \\
\end{array}$ & ఎo & 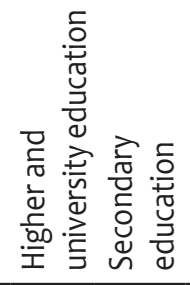 & 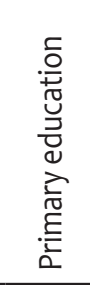 & 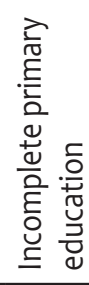 \\
\hline $\begin{array}{l}\text { The region of } A \text {. } \\
\text { P. of Vojvodina }\end{array}$ & 785.078 & 40,6 & $6,79 \quad 46,28$ & 27,54 & 19,24 \\
\hline Belgrade region & 314.596 & 19,0 & $9,27 \quad 55,19$ & 23,15 & 11,89 \\
\hline $\begin{array}{l}\text { The region of } \\
\text { Šumadija and } \\
\text { Western Serbia }\end{array}$ & 1.068 .149 & 52,6 & 39,78 & 28,25 & 26,02 \\
\hline $\begin{array}{l}\text { The region of } \\
\text { Southern and } \\
\text { Eastern Serbia }\end{array}$ & 747.167 & 47,8 & $4,94 \quad 36,72$ & 28,86 & 28,81 \\
\hline $\begin{array}{l}\text { The Republic of } \\
\text { Serbia in total }\end{array}$ & 2.914 .990 & 40,6 & $6,10 \quad 42,37$ & 27,68 & 23,42 \\
\hline
\end{tabular}

Source: Statistical Office of the Republic of Serbia (Republički zavod za statistiku), 2011 
to the other rural areas of RS. Namely, the economic power of Belgrade has an impact on the surrounding rural areas and enables the diversification of the rural economy towards the creation of the relatively strong non-agricultural sector. The vicinity of the large market impacts the structure of agricultural production, so a more intensive usage of land is present. The infrastructural equipment is at a much higher level and the service sector is accessible even in the urban center. The Belgrade region is the only region in RS where an increase in the rural population was recorded in the period between the last two censuses of the population and all the stated characteristics contributed to that (Zekić, Matkovski, 2015).

The overcoming of the relative development lagging of the rural areas is possible, primarily through the diversification of rural activities, i.e. the diversification of income or farm activities. Despite the fact that in the last few years a decrease in rural employment in agriculture and the processing industry, as well as an increase in the service sector, are present, the presence of rural activities in agriculture is still high - accounting for about $45 \%$. The reliance of the rural economy exclusively on agricultural production cannot be a viable concept of rural development anymore, since the primary sector cannot guarantee the social stability of the rural population. An income diversification is the strategy suitable for relatively poorer farms, which do not have possibilities to develop other profitable activities. Another strategy involves the diversification of the activities of agricultural farms, which is only achievable in the case of the economically stronger agricultural farm with the higher level of the education of its members. Rural tourism is often described as the sector suitable for the additional activity of an agricultural farm or a rural household in RS. It is estimated that in this sector there are about 10,000 beds and that there is an annual income of about RSD 10 billion, which is about $16 \%$ of the total income of the Serbian tourism (MPZŽS RS, 2014).

Such a way of income diversification includes certain funds which are usually all but negligible and for the majority of rural households it represents an insurmountable obstacle. Moreover, these activities are impossible without the particular managerial skills of some members of rural households. The low level of the infrastructural equipment of the rural areas reflected in the inadequate electric and road network and, often, in the absence of the sewer and water systems are a barrier as well. Also, the promotion of rural tourism in RS and especially abroad is inadequate. Out of the listed reasons, the majority of rural households diversify income, so income from employment and social income (pensions) account for more than twothirds of the total income (Table 2).

Despite the fact that agriculture represents the dominant economic activity in the rural areas, the share of the income of rural households in agriculture

Table 2 The income structure of the Serbian rural areas (\%)

\begin{tabular}{l|cccccccccc}
\hline & 2004 & 2005 & 2006 & 2007 & 2008 & 2009 & 2010 & 2011 & 2012 & 2013 \\
\hline Income from employment & 41.2 & 35.5 & 38.9 & 37.1 & 42.1 & 39.9 & 36.3 & 37.0 & 35.7 & 47.1 \\
Social income & 26.1 & 24.0 & 22.0 & 25.3 & 26.2 & 28.3 & 31.5 & 28.7 & 32.7 & 35.0 \\
Income from agriculture & 26.6 & 24.8 & 7.8 & 6.8 & 8.3 & 6.8 & 9.3 & 7.8 & 7.6 & 5.0 \\
Income from abroad & 1.7 & 2.0 & 2.3 & 2.3 & 1.3 & 2.0 & 1.2 & 1.6 & 2.1 & 1.6 \\
Income from property & 0.0 & 0.0 & 1.5 & 3.3 & 0.5 & 0.3 & 0.5 & 1.2 & 0.3 & 0.4 \\
Other income & 3.9 & 13.5 & 12.6 & 10.4 & 8.7 & 9.8 & 8.7 & 9.7 & 8.2 & 6.2 \\
Subsistence economy & 0.4 & 0.2 & 14.9 & 14.8 & 12.9 & 12.7 & 12.5 & 14.0 & 13.3 & 4.6 \\
\hline
\end{tabular}

Source: Bogdanov, Babović, 2014. 
is not the dominant one. The lower share of income from agriculture is conditioned by the inadequate structure of agricultural farms, i.e. the fragmentation of individual family farms (Cvijanović, Subić \& Paraušić, 2014) and the level of agricultural productivity is low as well (Zekić, Gajić \& Matkovski, 2013). At the regional level, the A. P. of Vojvodina is the dominant region in terms of agricultural income in the rural areas, which is the expected statistics, considering the average size of the farms and the level of the sector's productivity. On the other hand, the region of Southern and Eastern Serbia, with the dominant subsistent character of production, has a low level of agricultural income. In the Belgrade region, employment incomes are the dominant ones, which is expectable, considering the possibilities of employment in the large urban center, whereas the region of Šumadija and Western Serbia, as a response to the agrarian movement, has the largest share of farms with the second profitable activity (Bogdanov, Babović, 2014).

\section{THE BASIC CHARACTERISTICS OF THE IPARD FUNDS}

RS is a candidate for the EU membership and it is at the beginning of the negotiation process. The pre-accession period implies a wide spectrum of activities in the direction of the adaptation to the EU acquis communautaire, as well as the building of the institutions necessary for the successful functioning of the economic and the political systems. Due to the relatively large significance of agriculture in the economy of RS, the adaptation to the European Common Agricultural Policy (CAP) will represent a huge challenge, implying actions in the direction of: the harmonization of legislation, the strengthening of the institutions as well as change in the policy. The harmonization of legislation implies the creation of the legal basis for the implementation of the complex CAP regulations system, i.e. the right system for the country that can follow the necessary procedures for the implementation of the measures of this policy. Institution building implies the creation of an institution which should follow the efficient functioning of the CAP. In the end, the policy reforms imply the adoption of the EU standards with the aim of conducting a more efficient adaptation process (Bogdanov, 2015). In accordance with the current adaptation of the Serbian rural policy to the European one, it is necessary to build a complementary rural policy according to the current changes within the CAP that gives more freedom to countries to build the perennial plans of rural development and use them to define their own aims (Zekić, Matkovski, 2014). Although in the last period there was only a small progress in terms of harmonization with the acquis regulations, the implementation of the policy is only at its initial stage (European Commision, 2014a).

The EU has a relatively long tradition of supporting candidate countries (PHARE, ISPA, SAPARD et al.), and the IPA programme is the current one. The IPA programme of support consists of five components, the first two (Transition and Institution Building and Regional and Cross Border Cooperation) being available for candidate states and potential candidates, and the other three (Regional development, Strengthening of human resources and Rural development) being only available for candidate states. The IPARD programme is aimed at supporting the creation of a viable agrarian sector, as well as at increasing the economic vitality of rural areas. In comparison to IPARD-1 (20072013), IPARD-2 (2014-2020) is not directed across the priority axes, but through a larger number of certain supporting measures. The countries recipients have a possibility of choosing measures for which they will use the predicted support. Such an approach respects the specificities of the rural areas of each candidate country, which should, on the basis of the sector analyses and the analyses of the conditions in rural areas, direct the available support. Also, recipients' participation (around 50\%) as well as the country's $(25 \%)$ is obligatory.

At the beginning of 2015, the European Commission adopted IPARD-2 for RS, which should be financed until 2020 and which refers to: Investments in the Physical Assets of Agricultural Farms, Investments in the Physical Assets Concerning the Processing and Marketing of Agricultural and Fishery Products, Farm Diversification and Business Development and Technical Assistance. The agro-Environmental Climate and Organic Farming Measures, as well as Measures for the Preparation and Implementation of 
Local Development Strategies - the LEADER approach, are planned for 2017. In order to achieve access to the IPARD funds, RS had to prepare a document defining the measures of support to rural development, as well as the criteria and the financial framework. All had to be in accordance with the EU legislation. Documents like this are accredited by the Directorate General for Agriculture and Rural Development (DG AGRI), which represents just one of the conditions for access to the EU funds. The use of the IPARD programme implies institution building necessary for the implementation of this support. Those are the IPARD Agency (Directorate for Agrarian Payments), the Managing Authority (Sector for Rural Development MAEP), the Monitoring Committee and the National Fund. These institutions have a responsibility for making a selection of measures, their monitoring and evaluation, controlling financial flows, as well as performing the administrative tasks of receiving the applications, the implementation of control etc. By reporting on harmonization with the EU policy progress, it was estimated that, in 2014, RS had to make additional efforts to acquire accreditation for IPARD, whereas the report of 2015 states that a shift had been made due to the adoption of the IPARD programme for RS, but the further setting-up of the operational structures was yet necessary to be done (European Commission 2014b, European Commission 2015).

The predicted support of the EU for RS until 2020 amounts to EUR 175 million, provided that the predicted support for 2015 amounts to EUR4 15 million, and each following year the amount is increased by EUR 5 million, so that in the year 2020, it will reach the amount of EUR 45 million. RS has to provide about EUR 56 million, so the total public support will be about EUR 231 million. The largest amount of the support is aimed at the first two measures (investments) - 79\%. Among other measures, a slightly larger amount is only aimed at Farm Diversification and Business Development - 10\%. Recipients can be natural persons, i.e. registered agricultural farms, or legal entities with less than $25 \%$ of their capital held by the public bodies. For larger investments (more than EUR 50,000), a business plan in line with the template provided by the IPARD Agency is needed, whereas for smaller investments, those below EUR 50,000, it has to be in the simplified form (MPZŽS RS, 2014).

The specifically indicated sectors of the Serbian agriculture that will be IPARD's subject of financial support are: the production of milk, meat, fruits and vegetables, as well as other crops (cereals, oil-seeds, sugar beet). The IPARD programme of support implies the whole line of the criteria and rules on the manner of using the funds and the dynamics of financing. The sector analyses which should enable an insight into the state of the producer, the processor and the trade segment within each of the marked sectors of agriculture are the baseline. The defining of the specific needs of each specific segment, i.e. different productive units in particular sectors, should contribute to the process of making decisions on the approval of certain projects. All the farms that are going to make a request for support will have to meet the national standards of the Animal Welfare and Environmental Protection, and the subject of investment will have to fulfill the EU standards in these segments.

Investments in the Physical Assets of Agricultural Farms have the objective to enable their recipients to achieve the EU standards by means of building new and reconstructing the existing physical assets. Also, these measures should enable agricultural development through an increase in and the advancement of physical capital, as well as contribute to the resolution of the ecological issues. Namely, the low level of the competitiveness and productivity of the Serbian agriculture conditions the need for the technological advancement and modernization of mechanization. Within livestock production, primarily small and middle farms, which are highly present in the total milk production and meat, are in focus. The objectives are reflected in the improvement of the quality and quantity of produced milk and meat and the achievement of very high EU standards. Also, the objective is to restructure the size of the farm in the direction of the creation of economically viable production units. Large and specialized farms will have access to investments only in the case of their fulfilling the EU standards in terms of animal welfare and storage and distribution. Within crop production, support is predicted mainly for the improvement of mechanization, transporting and storage capacities, as 
well as for increasing yields through the improvement of agro-technological measures.

Unlike the first measure, where the final recipients are agricultural farms and other legal entities within the area of agriculture, in the case of Investments in the Physical Assets Concerning the Processing and Marketing of Agricultural and Fishery Products, the final recipients are enterprises. The stress is put on the improvement of processing, the storage capacities, the assortment development and energy efficiency, as well as the achievement of the EU standards in order to improve the competitiveness of the food processing sector. The aim of Farm Diversification and Business Development reflects in the diversification of the rural economy, primarily through the development of non-agricultural activities, and a reduction in an excessive dependence on agriculture. The primary aim is to improve the employment possibilities in the rural areas through the promotion of alternative activities on the agricultural farm. The focus is on rural tourism, respectively the training of the rural households for these activities. The final recipients are agricultural farms and other (micro- and small) legal entities within the area of agriculture. Technical Assistance should help in the implementation and monitoring of the IPARD programme, as well as in its eventual change. The recipient is the Managing Authority.

Agro-Environment-Climate and Organic Farming include a wide spectrum of actions in order to improve the quality of soil and water, biodiversity, the development of organic farming and adaptation to climate changes. The majority of the agro-environment programmes are directed towards the development of organic farming, primarily because this production is in accordance with the principles of the sustainable development of rural areas (Sarudi, Szakaly, Mathe \& Szente, 2003). The Preparation and Implementation of Local Development Strategies - the Leader approach should enable the promotion of the inclusion of local action groups in the preparation and implementation of the local projects of rural development. Namely, the objective is to acknowledge the specific needs of local areas, i.e. the local community, through the application of territorial access, bottom-up work, as well as the public-private partnership. Other Measures covered by the IPARD programme but unavailable in RS yet are: support for the establishment of groups of agricultural producers, the establishment and protection of forests, investments in the rural public infrastructure, the improvement of training and the advisory service.

\section{THE POSSIBILITIES AND RESTRICTIONS OF THE USAGE OF THE IPARD FUNDS IN THE RURAL DEVELOPMENT OF THE REPUBLIC OF SERBIA}

At the beginning of 2016, by improving the administrative capacities, RS gained a possibility of using the IPARD-2 funds. This development encouraged the positive expectations of the available EU funds and their positive impact on the rural areas and agriculture. The question is to which extent the pre-accession funds can be supportive of the development of the Serbian rural areas as well as how the same will be used. Additionally, it is uncertain who will gain the most benefits from the support formulated in that manner, intended for candidate countries. The exact answer to these questions cannot be provided in advance, but the significance of the EU pre-accession funds for the rural areas in RS can be anticipated.

In this regard, the experiences of the countries which have already had an opportunity to use similar funds, primarily the IPARD funds, are indicative. From 2007 to 2012, Croatia, Macedonia and Turkey received the support of EUR 130, 65 and 650 million, respectively, which is about the four-fifths of the total support intended for rural development.5 The largest part of these funds was used for investments in agricultural farms (39\%), investments in the development of processing and marketing (26\%), as well as in development and farm diversification (20\%). A considerably smaller amount of funds was used for other measures $(\leq 5 \%)$. Namely, all the three countries directed the largest amount of the funds towards Axis 1 - the improvement of efficiency and the reaching of the EU standards, around 70\%; for Axis 2 - the environment and the Leader approach, only between $2-5 \%$ of the funds was used, depending on the country, whereas for Axis 3 - the development of the rural economy, $23 \%$ of the funds was used. The rest of the 
funds was spent on the measures of technical support (around 2\%). In comparison to the other two countries, Croatia spent the largest part of the funds on Axis 3, the FYR of Macedonia on Axis 1, and Turkey on Axis 2 (European Commission, 2013).

In the context of the thus formulated EU support, as well as the current state in the Serbian agricultural sector, the largest potential benefits from the aspect of rural development can be realized if the largest possible amount of funds is directed towards smaller, economically viable farms with predominant livestock production. Namely, these farms are the basis of the social security of the rural population, where agriculture's role rather social than economic. However, small farms are under the biggest pressure, since they cannot be competitive, neither in terms of the quality nor the quantity, with larger agricultural farms which apply modern production methods and realize economies of scale. The increasingly stricter standards that are the consequence of approaching the EU membership are another problem. In this context, the contribution of these farms to the food security of the country should not be forgotten, which arises from the sector analyses for milk and meat, where the dominant part of the production is located on small semi-subsistence farms. However, it seems that family farms will not be the dominant ones when it comes to the attraction of the IPARD funds, although they represent the major users of arable land - around $82 \%$ of the utilized agricultural area (Statistical Office of the Republic of Serbia - Republički zavod za statistiku, 2012).

On the other hand, middle and large agricultural farms, whether their owners are natural or legal persons, represent the basis of agricultural modernization, contribute to the positive foreign-trade balance of the country in terms of agricultural products, and are generally concerned as the carriers of the progress within the agricultural sector. Everything listed is mostly undeniable; however, the question of the extent to which larger farms or agricultural enterprises contribute to the life quality of the local population, which represents the basic aim of rural development, is often ignored. The modern approach to rural development, among other things, focuses on smaller private farms and their role of protecting the rural values and the environment as well as enabling the existence of the larger part of the rural population. It should be stressed that the policy of rural development has to rely only on the agricultural farms which reach the bottom line of economic sustainability, which means that they at least satisfy the existential needs of the members of a farm. A large number of farms will not be able to fulfill this requirement, so there is an alternative in the form of the development of the non-agricultural sector, both on and outside farms, in order to make additional income sources for the rural population.

In this context, the milk sector is an indicative example. In RS, $1 / 4$ of farms produce cow milk, i.e. 156,000 agricultural farms with a little more than 431,000 of dairy cows. The agricultural farms with only 1-2 dairy cows, which are usually regarded as unviable, account for $70 \%$ of the farms which produce milk and $36 \%$ of the total number of the dairy cows. The slightly larger farms of 3-9 dairy cows represent $68 \%$ of the total production of milk and $59 \%$ of all the milk delivered to dairies. The large farms of more than 20, and even over 50 dairy cows, which are often regarded as the economic optimum, contribute to a lesser extent to the Serbian production of milk (MPZŽS RS, 2014). The milk sector is not the exception in the Serbian agriculture, which indicates the importance of small farms in terms of production. The IPARD funds would be a good basis for the improvement of milk production, primarily in terms of the improvement of the quality in order to achieve the very rigorous EU standards within this sector, which is the largest problem for small farms. Additionally, positive effects should be realized through an increase in yield per cow, i.e. the quantity of production. It primarily refers to the utilization of the funds from Investments in Physical Assets of Agricultural Farms, on whose account there is the largest amount of the funds. The previously mentioned suspicions of the ability of a large number of these farms to successfully apply for approaching the IPARD funds are justified. A similar situation is in the sector of meat production, which is in a slightly better position, in terms of the relatively simpler productive technology and a slightly easier way of reaching the standards. Here, it will also be good to direct the largest possible amount of funds towards 
small and middle-sized farms, which could improve the infrastructure and specialize their production to a larger extent. In general, in the sector of crop production, the situation is somewhat more favorable, since this sector has better productive performances and comparative advantages in the export. Still, certain improvements are necessary, primarily in terms of the storage capacities and mechanization.

If rural development is observed as the process of the improvement of the life quality of the rural population, then investments only in agricultural production will have a limited influence on it. In this sense, it will be the most effective if smaller and middle-sized farms manage to improve their production and achieve economic viability. This is especially characteristic of the highland area of Central Serbia, where the possibilities of the development of the rural areas are limited to a larger extent. Probably the measures presupposed for farms diversification and business development could significantly contribution to increasing income in the regions characterized by unfavorable conditions for agricultural production, for example, through investments in and the development of the capacities of rural tourism etc. The significance of this activity, especially for the EU candidate countries, is reflected in the contribution of rural tourism to the economic, social and ecological development of rural areas, which improves the life quality of the rural population (Hall, 2004). Unfortunately, the intended scale of the funds is relatively limited, so the expected domains cannot be larger. In the case of the A. P. of Vojvodina, the process of the enlargement of the agricultural farms is the most advanced - the average size of a farm is about 11 ha, and agricultural farms larger than 50 ha use more than one-half of the total arable area (Statistical Office of the Republic of Serbia - Republički zavod za statistiku, 2012), so it is logical to assume that the further process of agricultural modernization will only marginally contribute to rural development. In the A. P. of Vojvodina, the funds intended for legal entities with the aim of improving processing and marketing will probably have the largest effect since they provide the possibilities of the development of the activities indirectly linked to agricultural production.
However, what is common for the rural areas throughout RS is the necessity for searching for the alternative possibilities of applying, i.e. the additional sources of income for the rural population. The agroprocessing sector can serve to it only to a certain degree, since the creation of economically vital agricultural farms implies, apart from the intensification of production, their enlargement, and a reduction in the number of employees in the agrarian sector. Because of that, alternative sources of income have to be found in the development of non-agricultural activities, which should to a larger or lesser degree be linked to the primary sector, which is dominant in the Serbian rural areas. In the context of rural development, it seems that only an overall approach at the national level implying a series of coordinative measures -beginning with the demographic policy, via the educational policy, to health protection, infrastructural development, the agrarian and the tax policies etc. should lead to a significant shifting of the level of rural development. In other words, the integral policy of rural development includes a long-term approach with a wide spectrum of national interventions, which means that, in comparison to the IPARD-2 performances, much more time and support is necessary for the significant improvements of rural development.

\section{CONCLUSION}

The approximation of the Republic of Serbia to the EU represents a huge challenge for the whole socioeconomic system, the sector of the rural economy being no exception. The rural economy and agriculture have relative significance for the total Serbian economy, which additionally enlarges an interest in this sector in the pre-accession period. In addition to this, the contribution of the research, concentrated on the development problems of the rural areas and the IPARD funds as one of the ways of overcoming their economic lagging, has the largest importance in the identification of the relatively modest possibilities of the EU assistance. Also, the country's key role in increasing the effectiveness and efficiency of the utilization of the available funds and the establishment of the economic vitality of the rural areas are indicated. 
For the most part, the proposed hypotheses are not supportive of the usual way of thinking of the preaccession funds, so their testing gives somehow different access to the problem in comparison to the majority of the research studies conducted in this field. The hypotheses are confirmed to a greater extent, since it is clearly stated that the modernization of agriculture and the improvement of the life quality of the rural population do not have to be uniquely conditioned processes.

However, particular research limitations are present as well, as a result of the methodological difficulties in terms of the determination of the financial-support influence on the development processes. This can be useful to both the creators of the agricultural and the rural policies and the academics interested in the stated problematics.

Within analyses to be carried out in future papers, the position of the Serbian rural areas in comparison to the EU countries will be analyzed in order to further elaborate the development possibilities of these areas and the segments in which it would be justifiable to allocate the IPARD funds.

\section{ENDNOTES}

1 RS does not have an official statistical definition of rural areas, i.e. according to the methodology of the censuses of 1981, 1991, 2002 and 2011, the population is divided into the urban population and the other population, which implies the rural population.

2 From 2002 to 2011, between the two censuses of the population, the rural population decreased by 311,000 inhabitants, which amounts to $10.9 \%$, which is considerably more in comparison to the decrease in the urban population amounting to $4.15 \%$ (Statistical Office of the Republic of Serbia - Republički zavod za statistiku, 2011).

3 The Serbian rural areas will be analyzed on the basis of the four defined statistical regions at the NSTJ2 level (the National Nomenclature of Statistical Territorial Units Nomenklature statističkih teritorijalnih jedinica (NSTJ 2)): the A. P. of Vojvodina, Belgrade region, the region of Šumadija and Western Serbia and the region of Southern and Eastern Serbia. This division, adopted in 2010, relatively well reflects the heterogeneity of the Serbian rural areas.

4 In 2015, RS did not use the IPARD funds, so it is likely that the predicted support for 2015 will be transferred to 2016.

5 The data is not related to 2013.

\section{ACKNOWLEDGMENTS}

This paper is a part of the research Project (No. III 46006), which is funded by the Ministry of Education, Science and Technological Development of the Republic of Serbia.

\section{REFERENCES}

Bogdanov, N. (2007). Mala ruralna domaćinstva u Srbiji i ruralna nepoljoprivredna ekonomija. Beograd, Republika Srbija: UNDP.

Bogdanov, N. (2015). Ruralni razvoj i ruralna politika. Beograd, Republika Srbija: Poljoprivredni fakultet.

Bogdanov, N. i Babović, M. (2014). Radna snaga i aktionosti poljoprivrednih gazdinstva. Beograd, Republika Srbija: Republički zavod za statistiku.

Cvijanović, D., Subić, J. i Paraušić, V. (2014). Poljoprivredna gazdinstva prema ekonomskoj veličini $i$ tipu proizvodnje u Republici Srbiji. Beograd, Republika Srbija: Republički zavod za statistiku.

Čalić, M. Ž. (2004). Socijalna istorija Srbije, Beograd, Republika Srbija: Klio.

European Commission. (2013). Rural Development in the EU. Report 2013. Retrieved March 10, 2016, from http://ec.europa. eu/agriculture/statistics/rural-development/2013/full-text_ en.pdf

European Commission. (2014a). Instrument for Pre-accession Assistance (IPA II). Indicative strategy paper for Serbia 20142020. Retrieved March 10, 2016, from http://ec.europa.eu/ enlargement/pdf/key_documents/2014/20140919-csp-serbia. pdf

European Commission. (2014b). Serbia 2014 progress report. Retrieved March 10, 2016, from http://ec.europa.eu/ enlargement/pdf/key_documents/2014/20140108-serbiaprogress-report_en.pdf

European Commission. (2015). Serbia 2015 report. Retrieved March 17, 2016, from http://ec.europa.eu/enlargement/pdf/ key_documents/2015/20151110_report_serbia.pdf 
Gajić, M., \& Zekić, S. (2013). Development characteristics of agricultural sector in Serbia. In D. Škorić, D. Tomic \& V. Popovic (Eds), Agri-food Sector in Serbia - state and Challenges (pp.73-90). Belgrade, Republic of Serbia: Serbian Association of Agricultural Economists and Serbian Academy of Science and Art - Board for Village.

Hall, D. (2004). Rural Tourism Development in Southeastern Europe: Transition and the Search for Sustainability. International Journal of Tourism Research, 6(3), 165-176. doi: $10.1002 /$ jtr.482

Komazec, Lj., \& Aleksic, M. (2015). Organic agricultural production in the function of reducing rural poverty - The example of Velebit village in the A. P. of Vojvodina. Economic Horizons, 17(2), 151-159. doi: 10.5937/ekonhor1502155K

Lovre, K. (2013). Policy of Support to Agriculture and Rural Development. In D. Skorić, D. Tomić \& V. Popović (Eds), Agri-food Sector in Serbia - state and Challenges (pp. 233258). Belgrade, Republic of Serbia: Serbian Association of Agricultural Economists and Serbian Academy of Science and Art - Board for Village.

Matkovski, B. i Kleut, Ž. (2014). Integracioni procesi i politika ruralnog razvoja u funkciji konkurentnosti i ekonomske efikasnosti agroprivrede Srbije. Rad prezentovan na naučnom skupu: Strategijski menadžment i sistemi podrške odlučivanju u strategijskom menadžmentu, Subotica, Republika Srbija.

Ministarstvo poljoprivrede i zaštite životne sredine Republike Srbije (MPZŽS RS). (2014). Republika Srbija IPARD program za 2014-2020. godinu. Preuzeto 17.03.2016. sa http://www. mpzzs.gov.rs/wp-content/uploads/datoteke/korisna_ dokumenta/Serbia_IPARD_II_Program_finalni_prevodKorigovano_20_04_2015.pdf
Ristic, L. (2013). Strategic management of sustainable rural development in the Republic of Serbia. Economic Horizons, 15(3), 233-248. doi:10.5937/ekonhor1303229R

Republički zavod za statistiku. (2011). Popis stanovništva u Republici Srbiji u 2011. godini. Preuzeto 17.03.2016. sa www. stat.gov.rs.

Republički zavod za statistiku. (2012). Popis poljoprivrede $u$ Republici Srbiji u 2012. godini. Preuzeto 17.03.2016. sa www. stat.gov.rs.

Sarudi, C., Szakaly, Z., Mathe, A., \& Szente, V. (2003). The Role of Organic Agriculture in Rural Development. Agriculturae Conspectus Scientificus, 68(3), 197-202.

Zekić, S., \& Matkovski, B. (2014). New CAP reform and Serbian agriculture. In D. Cvijanović, J. Subić \& A. J. Vasile (Eds.), Sustainable agriculture and rural development in terms of the Republic of Serbia strategic goals realization within the Danube region - rural development and (un)limited resources (pp. 10951110). Belgrade, Republic of Serbia: Institute for Agricultural Economics.

Zekić, S. i Matkovski, B. (2015). Razvojne mogućnosti ruralnih područja Srbije. Zbornik Matice Srpske za društvene nauke, 66(4), 757-771.

Zekić, S., Gajić, M., \& Matkovski, B. (2013). Serbian agriculture in the regional and European integratons. In D. Tomić, M. Ševarlić, K. Lovre \& S. Zekić (Eds.), Challenges for the Global Agricultural Trade Regime After Doha (pp. 369-376). Belgrade, Republic of Serbia: Serbian Association of Agricultural Economists, Faculty of Economics in Subotica, University of Novi Sad.

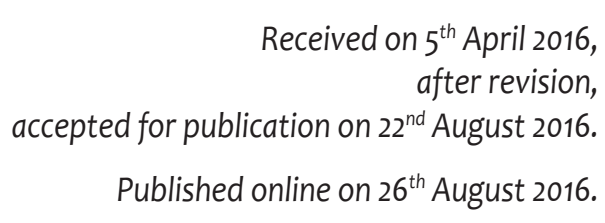

Received on $5^{\text {th }}$ April 2016, after revision, Published online on $26^{\text {th }}$ August 2016.

Stanislav Zekic is an Associate Professor at the Faculty of Economics in Subotica of the University of Novi Sad, in the scientific field of Agro-economics. He is the author and a co-author of a larger number of papers in the field of agrarian economics and rural development.

Bojan Matkovski is a Teaching Assistant at the Faculty of Economics in Subotica of the University of Novi Sad. He is a doctoral student in the field of agrarian economics.

Zana Kleut is a Teaching Associate at the Faculty of Economics in Subotica of the University of Novi Sad. She is a doctoral student in the field of agrarian economics. 


\title{
IPARD FONDOVI U FUNKCIJI RAZVOJA RURALNIH PODRUČJA REPUBLIKE SRBIJE
}

\author{
Stanislav Zekić*, Bojan Matkovski i Žana Kleut \\ Ekonomski fakultet u Subotici Univerziteta u Novom Sadu
}

\begin{abstract}
Sticanjem uslova za korišcenje pretpristupnih fondova Evropske unije, konkretno, sredstava namenjenih poljoprivredi i ruralnom razvoju (Instrument for Pre-accession Assistance in Rural Development - IPARD), Republici Srbiji (RS) biće pružena šansa da unapredi položaj poljoprivrednih gazdinstva, kao i stanje u ruralnim sredinama. Poljoprivreda ima specifičan značaj u privredi RS, a ruralna populacija čini skoro polovinu stanovništva, što dodatno povećava interes za ove fondove. S tim u vezi, cilj istraživanja je indentifikovati efekte korišćenja IPARD sredstava na razvoj ruralnih sredina, odnosno, društvenoekonomski progres ruralne populacije. Korišćena je kvalitativna deskriptivna analiza na osnovu empirijskih podataka. Osnovni zaključci su da će ovako struktuirana sredstava imati ograničen uticaj na smanjenje razvojnih nejednakosti i ostvarenje paritetnih uslova života između ruralnih i urbanih sredina. Naime, dominantna usmerenost IPARD sredstava ka investicijama u poljoprivredna gazdinstva i preduzeća, a ne ruralna domaćinstva, ograničava mogućnost njihovog snažnijeg uticaja na razvoj ruralnih sredina u RS.
\end{abstract}

Ključne reči: ruralni razvoj, IPARD fondovi, poljoprivreda, Republika Srbija, Evropska unija

JEL Classification: R11, R12, J11, J17, Q18

\section{UVOD}

Od 2016. godine za Republiku Srbiju (RS) bi trebala da se otvori mogućnost korišćenja pretpristupnih fondova Evropske unije (EU), tj. pete IPA (Instrument for Preaccession Assistance) komponente - IPARD (Instrument for Pre-accession Assistance in Rural Development). RS se tako po prvi put nalazi u situaciji da u većoj meri, kao zemlja kandidat, koristi fondove EU namenjene poljoprivredi i ruralnom razvoju. Važnost pristupa ovim sredstvima proizilazi iz relativnog

\footnotetext{
* Korespondencija: S. Zekić, Ekonomski fakultet u Subotici Univerziteta u Novom Sadu, Segedinski put 9-11, 24000 Subotica, Republika Srbija; e- mail: zekics@ef.uns.ac.rs
}

značaja koji poljoprivreda ima u ukupnoj privredi, a ruralna područja u društvu RS. Takođe, proizvodne performanse poljoprivredne, kao i agro-industrije, nisu na adekvatnom nivou (Gajić \& Zekić, 2013), a prisutno je i razvojno zaostajanja ruralnih područja u odnosu na ubrane sredine, kao i pojava siromaštva kao dominantno ruralnog fenomena (Bogdanov, 2007). Nepovoljne demografske tendencije, lošija obrazovna struktura, kao i nedostatak infrastrukture i neadekvatan uslužni sektor osnovne su karakteristike ruralnih područja, a ujedno i glavni razlog njihovog neadekvatnog položaja (Zekić i Matkovski, 2015). Pitanje je u kojoj meri ovakav vid eksterne podrške može doprineti rešavanju esencijalnih problema 
ruralne populacije, problema koji „vuku“ korene praktično još od osnivanja moderne srpske države (Čalić, 2004).

Politika ruralnog razvoja u RS usmerena je ka rastu konkurentnosti ruralne ekonomije, unapređenju kvaliteta života ruralne populacije, kao i zaštiti agrookruženja. Međutim, sredstva namenjena merama agrarnog budžeta za ostvarenje ovih ciljeva su relativno mala (Matkovski i Kleut, 2014). Ova politika je koncipirana tako da se oslanja na razvojne fondove, koji podstiču investicije u ruralna i nerazvijena područja, a neophodno je i dalje usaglašavanje institucija na regionalnom i lokalnom nivou, kako bi delovale kao jedinstven vertikalni sistem (Lovre, 2013).

Predmet istraživanja u radu je povezanost dostupnih IPARD sredstava i ruralnog razvoja RS, shvaćenog kao poboljšanje kvaliteta života ruralne populacije, odnosno, redukovanje nepovoljnih društvenoekonomskih tendencija u ruralnim područjima. Uticaj navedenih sredstava na poljoprivredno-prehrambeni sektor razmatran je $\mathrm{u}$ meri $\mathrm{u}$ kojoj se to odražava na nivo ruralne razvijenosti, pošto poljoprivreda, iako dominantna u ruralnim područjima RS, ne može biti jedini zamajac razvoja ruralnih sredina. $S$ tim u vezi, osnovni cilj istraživanja predstavlja procenjivanje potencijalnih efekata korišćenja ovih sredstava $u$ ruralnom razvoju RS.

U skladu sa navedenim predmetom i ciljem istraživanja, u radu se polazi od sledećih hipoteza:

H1: Pretpristupni fondovi EU namenjeni poljoprivredi i ruralnom razvoju imaće ograničen uticaj na ruralni razvoj Republike Srbije u smislu povećanja kvaliteta života ruralne populacije.

H2: Dominantna usmerenost IPARD sredstava ka investicionom ulaganju $u$ poljoprivredu RS neće značajno smanjiti ekonomsko zaostajanje ruralnih područja u odnosu na urbane sredine.

$\mathrm{Za}$ testiranje navedenih hipoteza korišćena je kvalitativna metodologija zasnovana na empirijskim podacima i deskriptivnoj analizi.

Polazna tačka istraživanja predstavlja analiza stanja u ruralnim područjima RS. Dalje je razmotrena struktura podrške iz IPARD fondova, te su identifikovane mogućnosti, ali i ograničenja uticaja ovih fondova na razvoj ruralnih područja u RS.

\section{SPECIFIČNOSTI RURALNIH PODRUČJA REPUBLIKE SRBIJE}

Ruralna područja, kao i sama poljoprivredna proizvodnja imaju specifičan značaj za ukupnu privredu RS. Naime, u zavisnosti od primenjene metodologije, ruralna područja zauzimaju između $75-90 \%$ teritorije RS, gde je nastanjeno oko $40-50 \%$ populacije $^{1}$, a primarni sektor zapošljava oko $20 \%$ radno aktivne populacije i stvara oko $10 \%$ bruto domaćeg proizvoda (BDP) (MPZŽS RS, 2014). Značaj poljoprivrede $\mathrm{u}$ ukupnoj privredi RS proističe iz povoljnih agro-ekoloških uslova, ali i iz nedovoljno razvijene ukupne privrede. Kao i kod većine drugih zemalja, ruralna područja RS pokazuju znake društveno-ekonomskog zaostajanja $u$ odnosu na urbane sredine. Ruralne sredine $u$ RS suočavaju se sa procesom starenja, siromašenja i pražnjenja, kao posledicom migracionih kretanja ka gradovima, pre svega, najsposobnijeg i najvitalnijeg dela stanovništva (Komazec \& Aleksic, 2015).

Jedan od najizraženijih problema predstavljaju nepovoljne demografske tendencije, koje su posledica, s jedne strane, višedecenijskog ekonomskog zaostajanja, a, sdruge strane, predstavljaju deo nepovoljnih ukupnih demografskih tendencija u RS. Drugim rečima, one su posledica niskog nataliteta i migracija, $\mathrm{u}$ gradove, i inostranstvo. Pad broja stanovnika u ruralnim sredinama dvostruko je veći u odnosu na smanjenje urbane populacije ${ }^{2}$,a najizraženiji je u Regionu Južne i Istočne Srbije ${ }^{3}$ (Republički zavod za statistiku, 2011). Pored smanjenja stanovništva, prisutna je i nepovoljna starosna struktura stanovništva. Naime, prosečna starost ruralnog stanovništva iznosi oko 43-44 godine, a svaki peti ruralni stanovnik je stariji od 65 godina. U Regionu Južne i Istočne Srbije situacija je još nepovoljnija, gde je prosečna starost 45,7 godina, dok je četvrtina populacije starija od 65 godina (MPZŽS RS, 2014). U cilju podsticanja mladih ljudi da ostanu da žive i rade u seoskim područjima, potrebno je povećati atraktivnost ovih područja za investicije (Ristic, 2013). 
Nepovoljne tendencije su prisutne i $u$ obrazovnoj strukturi, naročito u odnosu na urbanu populaciju. Veliki broj ruralnih stanovnika nema više od osnovnog obrazovanja, a veoma je malo onih sa visokim obrazovanjem. Najveći broj ima diplomu srednje škole, a dosta ih ima samo osnovnu školu. Beogradski region malo odskače od proseka, a i u Autonomnoj pokrajini Vojvodini je situacija nešto povoljnija. Obrazovna struktura je najnepovoljnija u Regionu Južne i Istočne Srbije, gde čak $58 \%$ stanovnika nema više od osnovnog obrazovanja, a čak polovina od njih nema završenu osnovnu školu. Stanje nije mnogo bolje ni u Regionu Šumadije i Zapadne Srbije, inače najruralnijem regionu RS (Tabela 1). Navedene tendencije su posebno karakteristične za žensku ruralnu populaciju, gde jedna trećina nije pohađala nikakvu školu i gde više od polovine nema nikakve kvalifikacije (MPZŽS RS, 2014).

Tabela 1 Ruralna populacija i obrazovna struktura u Republici Srbiji

\begin{tabular}{|c|c|c|c|c|c|c|}
\hline & $\begin{array}{l}\text { Ruralna } \\
\text { populacija }\end{array}$ & ১゚ & 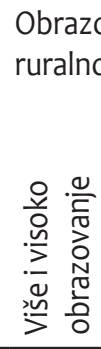 & 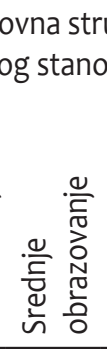 & 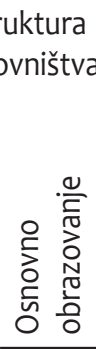 & 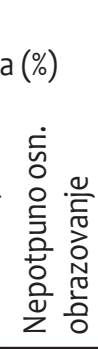 \\
\hline $\begin{array}{l}\text { Region } \\
\text { Vojvodine }\end{array}$ & 785.078 & 40,6 & 6,79 & 46,28 & 27,54 & 19,24 \\
\hline $\begin{array}{l}\text { Beogradski } \\
\text { region }\end{array}$ & 314.596 & 19,0 & 9,27 & 55,19 & 23,15 & 11,89 \\
\hline $\begin{array}{l}\text { Region } \\
\text { Šumadije } \\
\text { i Zapadne } \\
\text { Srbije }\end{array}$ & 1.068 .149 & 52,6 & 5,55 & 39,78 & 28,25 & 26,02 \\
\hline $\begin{array}{l}\text { Region Južne } \\
\text { i Istočne } \\
\text { Srbije }\end{array}$ & 747.167 & 47,8 & 4,94 & 36,72 & 28,86 & 28,81 \\
\hline $\begin{array}{l}\text { Republika } \\
\text { Srbija } \\
\text { ukupno }\end{array}$ & 2.914 .990 & 40,6 & 6,10 & 42,37 & 27,68 & 23,42 \\
\hline
\end{tabular}

Izvor: Republički zavod za statistiku, 2011.
Navedena obrazovna i starosna struktura stanovništva predstavlja najveću kočnicu razvoju ruralnih područja, odnosno, veoma negativno utiče na proces modernizacije poljoprivrede, a naročito na proces razvoja nepoljoprivrednog sektora. Ovo je posebno karakteristično za ruralna područja južno od Beograda, gde dominiraju sitna polu-naturalna gazdinstva sa ekstenzivnom poljoprivrednom proizvodnjom i skromnim mogućnostima za zaposlenje izvan poljoprivrede. Situacija je nešto povoljnija u Regionu Šumadije i Zapadne Srbije, gde ima dosta gazdinstva koja ostvaruju dodatne izvore prihoda, a ovaj region prednjači i u razvoju ruralnog turizma u odnosu na druga ruralna područja u RS. Takođe, infrastrukturna opremljenost je na višem nivou u odnosu na Region Južne i Istočne Srbije, gde postoje znatna infrastrukturna ograničenja. Inače, $\mathrm{u}$ ovom regionu ruralno siromaštvo je najviše izraženo $i$ to, pre svega, kao posledica negativnih tendencija $u$ većini društveno-ekonomskih karakteristika (Zekić i Matkovski, 2015).

Situacija je povoljnija kada je u pitanju Beogradski region i Region AP Vojvodine. Prednosti AP Vojvodine ogledaju se $\mathrm{u}$ prirodnim pogodnostima, kao i specifičnim istorijsko-razvojnim karakteristikama, koje su omogućile bolju infrastrukturnu snabdevenost, kao i razvijeniji uslužni sektor. Takođe, razvijenost poljoprivredne proizvodnje, kao dominantne delatnosti ruralnih područja, je na višem nivou, a poljoprivredna gazdinstva su u velikoj meri ekonomski održiva. S druge strane, usled snažnog ekonomskog uticaja velike urbane sredine, Beogradski region je sam po sebi netipičan u odnosu na druga ruralna područja RS. Naime, privredna moć Beograda se preliva $\mathrm{u}$ okolna seoska područja, omogućavajući diverzifikaciju ruralne ekonomije $u$ pravcu stvaranja relativno snažnog nepoljoprivrednog sektora. Blizina velikog tržišta odražava se i na strukturu poljoprivredne proizvodnje u pravcu intenzivnije upotrebe zemljišta. Infrastrukturna opremljenost je na višem nivou, a uslužni sektor je pristupačan i u urbanom centru. Sve navedene karakteristike su doprinele da Beogradski region bude jedini u RS gde je zabeležen rast ruralne populacije $u$ periodu između poslednja dva popisa stanovništva (Zekić i Matkovski, 2015). 
Prevazilaženje relativne razvojne zaostalosti ruralnih područja moguće je ostvariti, pre svega, kroz diverzifikaciju ruralnih aktivnosti, tj. diverzifikaciju prihoda i aktivnosti ruralnih gazdinstava. Iako je $u$ poslednjih nekoliko godina došlo do smanjenja ruralne zaposlenosti u poljoprivredi i prerađivačkoj industriji, a rasta u uslužnom sektoru, vezanost ruralnih aktivnosti za poljoprivredu je i dalje visoka - oko $45 \%$. Oslanjanje ruralne ekonomije isključivo na poljoprivrednu proizvodnju više ne može biti održiv koncept ruralnog razvoja, pošto primarni sektor ne može predstavljati garant socijalne sigurnosti ruralne populacije. Diverzifikacija prihoda je strategija pogodna relativno siromašnijim gazdinstvima, koja nemaju mogućnosti da razviju druge profitabilne aktivnosti. Druga strategija podrazumeva diverzifikaciju aktivnosti poljoprivrednog gazdinstva, a ostvariva je samo kod ekonomski snažnijih ruralnih domaćinstava sa višim nivoom obrazovanja članova domaćinstva. Ruralni turizam se često apostrofira kao sektor pogodan za dodatnu aktivnost poljoprivrednog gazdinstva ili ruralnog domaćinstva u RS. Procena je da u ovom sektoru postoji oko 10.000 ležajeva, i da se ostvaruje oko 10 milijardi dinara prihoda godišnje, što čini oko 16\% ukupnog prihoda turizma u RS (MPZŽS RS, 2014).

Ovakav način diverzifikacije prihoda podrazumeva određena finansijska sredstva, koja nisu mala, što za većinu ruralnih domaćinstava predstavlja nepremostivu prepreku. Pored toga, ovakve aktivnosti nisu moguće bez menadžerskih sposobnosti članova ruralnih domaćinstava. Ograničenje predstavlja i nizak nivo infrastrukturne opremljenosti seoskih sredina, što se ogleda u neadekvatnoj električnoj i putnoj mreži, i često nepostojanju kanalizacionih i vodovodnih sistema. Takođe, neadekvatna je promocija ruralnih turističkih kapaciteta, u zemlji i inostranstvu. Iz navedenih razloga, većina ruralnih domaćinstava u RS diverzifikuju izvore prihoda, pa tako prihodi iz radnog odnosa i socijalna primanja (penzije) čine preko dve trećine ukupnih prihoda (Tabela 2).

Iako poljoprivreda predstavlja dominantnu privrednu delatnost $\mathrm{u}$ ruralnim područjima, udeo prihoda ruralnih domaćinstava iz poljoprivrede to nije. Niži udeo prihoda iz poljoprivrede uslovljen je neadekvatnom strukturom poljoprivrednih gazdinstava, tj. usitnjenošću individualnog poseda (Cvijanović, Subić i Paraušić, 2014), a nizak je i nivo produktivnosti poljoprivrede (Zekić, Gajić \& Matkovski, 2013). Regionalno posmatrano, pod prihodima iz poljoprivrede $\mathrm{u}$ ruralnim područjima prednjači AP Vojvodina, što je i očekivana s obzirom na prosečnu veličinu gazdinstava i nivo produktivnosti sektora. S druge strane, Region Južne i Istočne Srbije, sa dominantnim naturalnim karakterom proizvodnje, ima nizak nivo prihoda iz poljoprivrede. U Beogradskom regionu dominiraju prihodi iz radnog odnosa, što je i očekivano usled mogućnosti zaposlenja $\mathrm{u}$ velikom urbanom centru, dok Region Šumadije i Zapadne Srbije, kao odgovor na agrarnu prenaseljenost

Tabela 2 Struktura prihoda ruralnih domaćinstava u Republici Srbiji (\%)

\begin{tabular}{l|cccccccccc}
\hline & 2004. & 2005. & 2006. & 2007. & 2008. & 2009. & 2010. & 2011. & 2012. & 2013. \\
\hline Prihodi iz radnog odnosa & 41,2 & 35,5 & 38,9 & 37,1 & 42,1 & 39,9 & 36,3 & 37,0 & 35,7 & 47,1 \\
Socijalna primanja & 26,1 & 24,0 & 22,0 & 25,3 & 26,2 & 28,3 & 31,5 & 28,7 & 32,7 & 35,0 \\
Prihodi od poljoprivrede & 26,6 & 24,8 & 7,8 & 6,8 & 8,3 & 6,8 & 9,3 & 7,8 & 7,6 & 5,0 \\
Prihodi iz inostranstva & 1,7 & 2,0 & 2,3 & 2,3 & 1,3 & 2,0 & 1,2 & 1,6 & 2,1 & 1,6 \\
Prihodi od imovine & 0,0 & 0,0 & 1,5 & 3,3 & 0,5 & 0,3 & 0,5 & 1,2 & 0,3 & 0,4 \\
Ostala primanja & 3,9 & 13,5 & 12,6 & 10,4 & 8,7 & 9,8 & 8,7 & 9,7 & 8,2 & 6,2 \\
Naturalna razmena i potrošnja & 0,4 & 0,2 & 14,9 & 14,8 & 12,9 & 12,7 & 12,5 & 14,0 & 13,3 & 4,6 \\
\hline
\end{tabular}

Izvor: Bogdanov i Babović, 2014. 
ima najveći udeo gazdinstva sa drugom profitabilnom aktivnošću (Bogdanov i Babović, 2014).

\section{OSNOVNE KARAKTERISTIKE IPARD FONDOVA}

Republika Srbija je zemlja kandidat za članstvo $\mathrm{u}$ EU. Inače, pretpristupni period podrazumeva širok spektar aktivnosti u pravcu prilagođavanja tekovinama EU (acquis communautaire), kao i izgradnju institucija neophodnih za uspešno funkcionisanje novog ekonomskog i političkog sistema. Usled relativno velikog značaja poljoprivrede $\mathrm{u}$ privredi RS, prilagođavanje Zajedničkoj agrarnoj politici EU (ZAP), predstavljaće veliki izazov, a podrazumeva akcije u pravcu: harmonizacije zakonodavstva, jačanja institucija, kao i promena u samoj politici. Harmonizacija zakonodavstva podrazumeva stvaranje pravne osnove za sprovođenje kompleksnog sistema regulativa ZAP, tj. osposobljavanje pravnog sistema zemlje da sprovede procedure neophodne za implementaciju mera ove politike. Institucionalna izgradnja u osnovi znači stvaranje institucija koje treba da omoguće efikasno funkcionisanje ZAP. Reforme politike podrazumevaju usvajanje standarda EU, u cilju što efikasnijeg procesa prilagođavanja (Bogdanov, 2015). U skladu sa aktuelnim prilagođavanjem ruralne politike RS evropskoj, potrebno je izgraditi komplementarnu ruralnu politiku u skladu sa aktuelnim promenama u okviru ZAP-a koje daju veću slobodu državama da same izrade višegodišnje planove ruralnog razvoja, kojima će definisati sopstvene ciljeve (Zekić i Matkovski, 2014). Iako je u proteklom periodu načinjen mali progres $u$ harmonizaciji sa propisima acquis-a, implementacija politika je tek u početnom stadijumu u većini oblasti (European Commision, 2014a).

EU ima dugu tradiciju podrške zemljama kandidatima (PHARE, ISPA, SAPARD i dr.), a trenutno je aktuelan IPA program. IPA program podrške sadrži pet komponenata, prve dve (Tranzicija i izgradnja institucija i Regionalna i prekogranična saradnja) dostupne su kandidatima i potencijalnim kandidatima, a ostale tri (Regionalni razvoj, Jačanje ljudskih resursa i Ruralni razvoj) samo zemljama kandidatima. Cilj
IPARD programa je pomoć pri stvaranju održivog agrarnog sektora, kao i povećanje ekonomske vitalnosti ruralnih područja. U odnosu na IPARD-1 (2007-2013), IPARD-2 (2014-2020) nije usmeren preko prioritetnih osa, već kroz veći broj određenih mera podrške. Državama korisnicama ostavljena je mogućnost da sami biraju mere za koje će koristiti predviđena sredstva. Ovakav pristup uvažava specifičnosti ruralnih područja svake zemlje kandidata, koje bi trebalo da na osnovu sektorskih analiza i analize stanja u ruralnim područjima, usmeravaju dostupna sredstva. Takođe, obavezna je participacija korisnika sredstava (oko $50 \%$ ), kao i države korisnice $(25 \%$ od ukupnih javnih sredstava).

Evropska komisija je početkom 2015. usvojila IPARD-2 za RS, koje bi trebalo da budu finansirane do 2020, a odnose se na: Investicije $u$ fizičku imovinu poljoprivrednih gazdinstava, Investicije $\mathrm{u}$ fizičku imovinu u vezi sa preradom i marketingom poljoprivrednih proizvoda i proizvoda ribarstva, Diverzifikaciju poljoprivrednih gazdinstava i razvoja poslovanja i Tehničku pomoć. Agro-ekološkoklimatske mere i mere organske proizvodnje, kao i Mere za pripremu i implementaciju Leader pristupa, predviđene su od 2017. Da bi RS ostvarila pristup sredstvima iz IPARD-a, morala je da pripremi dokument kojim se definišu mere za podršku ruralnom razvoju, kao i kriterijume i finansijske okvire, u skladu sa aktuelnim regulativama EU. Ovakav dokument se akredituje od strane Direktorata za poljoprivredu EU (DG AGRI), što predstavlja jedan od uslova za pristup fondovima EU. Primena IPARD programa podrazumeva i izgradnju nacionalnih institucija, neophodnih za sprovođenje ove podrške. To su IPARD agencija (Uprava za agrarna plaćanja), Upravljačko telo (Sektor za ruralni razvoj MPZZS), Nadzorno telo (Odbor za praćenje) i Nacionalni fond. Ove institucije imaju zadatak da obavljaju izbor mera, njihovo praćenje i evaluaciju, finansijski tok novca, kao i administrativne poslove oko prijema prijava, sprovođenja kontrole i slično. Izveštajem o napretku harmonizacije sa politikom EU, u 2014. je ocenjeno da RS mora uložiti dodatne napore za sticanje akreditacije za IPARD, dok je u izveštaju 2015. navedeno da je načinjem pomak zbog usvajanja IPARD programa za RS, ali je neophodno dalje uspostavljanje operativnih 
struktura (European Commision 2014b, European Commision 2015).

Ukupno predviđena sredstva za RS do 2020, od strane EU, iznose 175 miliona evra, s tim da je u 2015. predviđeni iznos 15 miliona evra ${ }^{4}$, a svake naredne godine iznos se povećava za 5 miliona evra, da bi u 2020. godini dostigao 45 miliona evra. RS treba da obezbedi oko 56 miliona evra, tako da će ukupna javna pomoć iznositi oko 231 milion evra. Najveći iznos sredstava predviđen je za prve dve mere (investiciono ulaganje) - 79\%. Od drugih mera, veći iznos je predviđen samo za Diverzifikaciju poljoprivrednih gazdinstava i razvoj poslovanja - 10\%. Korisnici mogu biti fizička lica, tj. registrovana poljoprivredna gazdinstva ili pravna lica sa manje od $25 \%$ javnog kapitala. Za veće investicija (preko 50.000 evra) potreban je biznis plan urađen $\mathrm{u}$ skladu sa formom pripremljenom od IPARD agencije, dok je za investicije manje od 50.000 evra potrebna pojednostavljena verzija biznis plana (MPZŽS RS, 2014).

Posebno naznačeni sektori $u$ poljoprivredi RS, koji će biti predmet finansiranje od strane IPARD-a, su: proizvodnja mleka, mesa, voća i povrća, kao i drugi usevi (žitarice, uljarice, šećerna repa). Program podrške kroz IPARD sredstva podrazumeva niz kriterijuma i pravila o načinu korišćenja sredstava, i o dinamici finansiranja. Polaznu osnovu predstavljaju sektorske analize, koje treba da omoguće uvid u stanje kod proizvođača, prerađivača, kao i stanje $\mathrm{u}$ tržišnom segmentu kod svakog od markiranih sektora poljoprivrede. Definisanju specifičnih potreba svakog specifičnog segmenta, tj. različitih proizvodnih jedinica u pojedinim sektorima, treba da doprinese procesu donošenja odluka o odobravanju pojedinih projekata. Sva gazdinstva koja budu konkurisala za sredstva moraće da ispune nacionalne standarde $u$ oblasti dobrobiti životinja i zaštite životne sredine, a sam predmet investicije moraće da ispunjava standarde EU u ovim segmentima.

Investicije $\mathrm{u}$ fizičku imovinu poljoprivrednih gazdinstava imaju za cilj omogućavanje poljoprivrednicima dostizanje standarda EU, putem izgradnje novih, kao i rekonstrukcije postojećih objekata i opreme na gazdinstvima. Takođe, ove mere treba da omoguće razvoj poljoprivrede kroz rast i unapređenje fizičkog kapitala, ali i da doprinesu rešavanju ekoloških problema. Naime, nizak nivo konkurentnosti i produktivnosti poljoprivrede RS uslovljava potrebu za tehnološkim poboljšanjima i modernizacijom mehanizacije. Kod stočarske proizvodnje, $\mathrm{u}$ fokusu su prvenstveno mala i srednja gazdinstva, veoma zastupljena u ukupnoj proizvodnji mleka, ali i mesa. Ciljevi su povećanje kvaliteta i količine proizvedenog mleka i mesa, i dostizanje, standarda EU. Takođe, cilj je restrukturiranje veličine gazdinstava u pravcu stvaranja ekonomski održivih proizvodnih jedinica. Velika i specijalizovana gazdinstva će imati pristup investicijama samo kod dostizanja standarda EU u sferi dobrobiti životinja i skladištenja i distribucije stajnjaka. Kod biljne proizvodnje podrška je predviđena uglavnom za unapređenje mehanizacija, transportnih i skladišnih kapaciteta, i za povećanje prinosa kroz poboljšanje agro-tehnoloških mera.

Za razliku od prve mere, gde su krajnji korisnici poljoprivredna gazdinstva i druga pravna lica iz oblasti poljoprivrede, kod Investicija u fizičku imovinu u vezi sa preradom i marketingom poljoprivrednih proizvoda i proizvoda ribarstva, krajnji korisnici su preduzeća. Naglasak je na unapređenju prerađivačkih i skladišnih kapaciteta, razvoju asortimana i energetske efikasnosti, i dostizanju standarda EU, a u cilju unapređenja konkurentnosti prehrambeno-prerađivačkog sektora. Diverzifikacija poljoprivrednih gazdinstava i razvoja poslovanja ima za cilj diverzifikaciju ruralne ekonomije, pre svega, kroz razvoj nepoljoprivrednih aktivnosti i smanjivanje velike zavisnosti od poljoprivrede. Prevashodni cilj je unapređenje mogućnosti zaposlenja $\mathrm{u}$ ruralnim područjima, kroz promociju alternativnih aktivnosti na poljoprivrednom gazdinstvu. Fokus je na ruralnom turizmu, odnosno, osposobljavanju ruralnih domaćinstva za obavljanje ovih aktivnosti. I ovde su krajnji korisnici poljoprivredna gazdinstva i druga (mikro i mala) pravna lica iz oblasti poljoprivrede. Tehnička pomoć treba da pomogne u sprovođenje i nadzoru IPARD programa, kao i u njegovoj eventualnoj izmeni. Korisnik je Upravljačko telo IPARD programa.

Agro-ekološko-klimatske mere i mere organske proizvodnje obuhvataju širok spektar akcija u cilju unapređenja kvaliteta zemljišta i vode, biodiverziteta, razvoj organske poljoprivrede, kao 
i prilagođavanje klimatskim promenama. Većina agro-ekoloških programa usmerena je ka razvoju organske proizvodnje, jer je ova proizvodnja $u$ skladu sa principima održivog ruralnog razvoja (Sarudi, Szakaly, Mathe \& Szente, 2003). Mere za pripremu i implementaciju Leader pristupa treba da omoguće promociju uključivanja lokalnih akcionih grupa u pripremu i sprovođenje lokalnih projekata ruralnog razvoja. Naime, cilj je uvažavanje specifičnih potreba lokalne sredine, tj. lokalnog stanovništva, putem primene teritorijalnog pristupa, botom-up principa, kao i javno-privatnog partnerstva. Ostale mere obuhvaćene IPARD programom, a nedostupne RS su: podrška za uspostavljanje proizvođačkih grupa, uspostavljanje i zaštita šuma, investicije u ruralnu javnu infrastrukturu, unapređenje obuke i savetodavne usluge.

\section{MOGUĆNOSTI I OGRANIČENJA KORIŠĆENJA IPARD SREDSTAVA U RURALNOM RAZVOJU REPUBLIKE SRBIJE}

Unapređenjem administrativnih kapaciteta, RS je početkom 2016. stekla mogućnost korišćenja sredstava iz IPARD-2 fonda. Ovakav razvoj ohrabrio je pozitivna očekivanja od dostupnih fondova EU i njihovog pozitivnog uticaja na ruralna područja i poljoprivredu. Pitanje je koliko pretpristupni fondovi zaista mogu biti oslonac razvoja ruralnih sredina $u$ RS, kao i to na kakav način će biti iskorišćeni. Dodatno pitanje je i ko će najviše imati koristi od ovako formulisane podrške, namenjene zemljama kandidatima. Naravno da se na ova pitanja ne mogu unapred dati precizni odgovori, ali se može anticipirati značaj pretpristupnih fondova Unije za ruralna područja RS.

U ovom smislu indikativna mogu biti iskustva zemalja koje su već imale priliku da koriste slične fondove, pre svega IPARD sredstava. Hrvatska, BJR Makedonija i Turska su u periodu 2007-2012, povukla sredstva u iznosu od 130, 65 i 650 miliona evra, respektivno, što čini oko četiri petine od ukupno namenjenih sredstava za ruralni razvoj ${ }^{5}$. Najveći deo ovih sredstava bio je usmeren ka investicijama u poljoprivredna gazdinstva (39\%), investicijama u razvoj prerade i marketing
(26\%), kao i na razvoj i diverzifikaciju poljoprivrednih gazdinstava (20\%). Znatno manji iznos sredstava korišćen je za druge mere $(\leq 5 \%)$. Naime, sve tri zemlje su najveći iznos sredstava usmerile ka Osi 1 unapređenje efikasnosti i dostizanje EU standarda, oko 70\%. Za Osu 2 - životna sredina i Leader pristup, iskorišćeno je samo između 2-5\% u zavisnosti od države, dok je na Osu 3 - razvoj ruralne ekonomije, iskorišćeno $23 \%$ sredstava. Ostatak sredstava je utrošen na mere tehničke podrške (oko 2\%). U odnosu na druge dve zemlje, Hrvatska je najviše sredstava utrošila na treću osu, Makedonija na prvu, a Turska na drugu osu (European Commission, 2013).

U kontekstu ovako formulisane pomoći EU, kao i trenutnog stanja $\mathrm{u}$ poljoprivrednom sektoru RS, najveće potencijalne koristi sa aspekta ruralnog razvoja, mogle bi se ostvariti kada bi što veći iznos sredstava bio usmeren ka manjim, ekonomski održivim, gazdinstvima sa pretežno stočarskom proizvodnjom. Naime, ovakva gazdinstva predstavljaju osnov socijalne sigurnosti ruralne populacije, gde poljoprivreda ima više socijalnu nego ekonomsku ulogu. Međutim, sitna gazdinstva se nalaze pod najvećim pritiskom, jer u pogledu kvantiteta i kvaliteta ne mogu da budu konkurentna sa većim poljoprivrednim gazdinstvima koja praktikuju moderne proizvodne metode i ostvaruju ekonomiju obima. Poseban problem predstavljaju i sve stroži standardi koji donosi približavanje članstvu u EU. U ovom kontekstu, ne treba zaboraviti i doprinos ovakvih gazdinstava prehrambenoj sigurnosti zemlje, što proizilazi iz sektorskih analiza za mleko i meso, gde je dominantan deo proizvodnje lociran na malim polunaturanim gazdinstvima. Međutim, čini se da porodična gazdinstva neće dominirati kada je privlačenje IPARD sredstava u pitanju, iako predstavljaju većinskog korisnika obradivih površina oko 82\% korisnih poljoprivrednih površina (Republički zavod za statistiku, 2012).

S druge strane, srednja i velika poljoprivredna gazdinstva, bilo da su u pitanju individualni vlasnici ili pravna lica, predstavljaju osnov modernizacije poljoprivrede, doprinose pozitivnom spoljnotrgovinskom bilansu zemlje kod agrarnih proizvoda, te se, generalno smatraju nosiocima progresa $u$ poljoprivrednom sektoru. Sve navedeno je, uglavnom, 
neosporno. Međutim, ono što se često gubi iz vida je pitanje u kojoj meri veća gazdinstva ili poljoprivredna preduzeća doprinose kvalitetu života lokalne populacije, što predstavlja osnovni cilj ruralnog razvoja. Savremeni pristup ruralnom razvoju, između ostalog, fokus stavlja na manja individualna gazdinstvima i njihovu ulogu kako u očuvanju ruralnih vrednosti i životne sredine, tako i u obezbeđivanju egzistencije velikog dela ruralnog stanovništva. Naravno, treba naglasiti da se politika ruralnog razvoja mora oslanjati samo na ona poljoprivredna gazdinstva koja dostižu donji prag ekonomske održivosti, što bi značilo da obezbeđuju zadovoljenje bar egzistencijalnih potreba za članove gazdinstva. Veliki broj gazdinstava neće moći da ispuni ovaj zahtev, pa se kao alternativa pretpostavlja razvoj nepoljoprivrednog sektora, kako na samim gazdinstvima, tako i izvan njih, a sve $\mathrm{u}$ cilju stvaranja dodatnih izvora prihoda za ruralnu populaciju.

$\mathrm{U}$ ovom kontekstu, indikativan je primer sektora mleka. U RS, 1/4 gazdinstava proizvodi kravlje mleko, odnosno, oko 156 hiljada poljoprivrednih gazdinstava sa nešto preko 431 hiljade muznih grla. Poljoprivrednih gazdinstava sa samo 1-2 muzne krave, što se obično smatra neodrživim, je čak $70 \%$ gazdinstava koja proizvode mleko, i $36 \%$ od broja muznih krava. Nešto veća gazdinstva sa 3-9 muznih krava čine čak $68 \%$ ukupne proizvodnje mleka, s tim da se $59 \%$ mleka isporučuje mlekarama. Velika poljoprivredna gazdinstva sa preko 20, i preko 50 muznih krava, koja se smatraju ekonomskim optimumom, u manjoj meri doprinose proizvodnji mleka u RS (MPZŽS RS, 2014). Sektor mleka nije izuzetak u poljoprivredi RS, što govori o značaju malih gazdinstava i u proizvodnom smislu. IPARD fondovi bi mogli biti dobar oslonac za unapređenje proizvodnje mleka i to, pre svega, kod podizanja kvaliteta mleka i ispunjavanja standarda EU, koji su u ovom sektoru veoma strogi, a sa čim mala gazdinstva imaju najviše problema. Takođe, pozitivni efekti mogli bi se ostvariti i kod rasta mlečnosti, odnosno, kvantiteta proizvodnje. Ovde se, pre svega, misli na korišćenje sredstava iz mera Investiranja $\mathrm{u}$ fizičku imovinu poljoprivrednih gazdinstava, na čijem se kontu nalazi najveći iznos sredstava. Opravdane su sumnje u sposobnost velikog dela ovakvih gazdinstava u mogućnost uspešne aplikacije za pristup IPARD sredstvima.

Slična situacija je u sektoru proizvodnje mesa, koji je $\mathrm{u}$ boljem položaju, u smislu relativno jednostavnije tehnologije proizvodnje, i lakšeg dostizanja standarda. I ovde bi bilo dobro da što više sredstava ode ka malim i srednjim gazdinstvima, koja bi mogla da unaprede infrastrukturu i u većoj meri specijalizuju proizvodnju.

Generalno posmatrano, kod biljne proizvodnje situacija je nešto povoljnija, pošto ovaj sektor beleži bolje proizvodne performanse, ali i komparativne prednosti u izvozu. Ipak, i ovde su neophodna određena poboljšanja, pre svega, kod skladišnih kapaciteta i mehanizacije.

Ako ruralni razvoj posmatramo kao proces poboljšanja kvaliteta života ruralne populacije, onda će ulaganja samo u poljoprivrednu proizvodnju imati na njega ograničen domet. U ovom smislu, najveći efekat bi se postigao kada bi manja i srednja gazdinstva uspela da unaprede proizvodnju i postignu ekonomsku održivost. Ovo je posebno karakteristično za brdsko-planinska područja Centralne Srbije, gde su mogućnosti razvoja ruralnih sredina u velikoj meri limitirane. Verovatno bi mere predviđene za diverzifikaciju poljoprivrednih gazdinstava i razvoj poslovanja mogle imati značajniji doprinos rastu dohotka $\mathrm{u}$ regionima sa nepovoljnim uslovima za poljoprivrednu proizvodnju, na primer, kroz ulaganja $\mathrm{u}$ razvoj kapaciteta $\mathrm{u}$ ruralnom turizmu i slično. Značaj ove aktivnosti, pogotovo za zemlje kandidate za članstvo u EU, ogleda se u doprinosu ruralnog turizama ekonomskom, socijalnom i ekološkom razvoju seoskih područja, što povećava kvalitet života ruralne populacije (Hall, 2004). Na žalost, predviđeni obim ovih sredstava je relativno ograničen, te i očekivani dometi ne mogu biti veći. Što se AP Vojvodine tiče, proces ukrupnjavanja poljoprivrednih gazdinstva je najviše odmakao - prosečna veličina poseda je oko 11 ha, a gazdinstva preko 50 ha koriste preko polovine od ukupnog obradivog zemljišta (Republički zavod za statistiku, 2012), pa je logično pretpostaviti da će dalji proces modernizacije poljoprivrede samo marginalno doprineti ruralnoj razvijenosti. U AP Vojvodini će sredstva namenjena pravnim licima u cilju unapređenja prerade i marketinga verovatno imati 
najveći efekat, pošto otvaraju mogućnost unapređenja razvoja aktivnosti, koje nisu direktno vezane za poljoprivrednu proizvodnju.

Međutim, ono što je zajedničko za ruralne sredine u svim delovima RS je potreba za pronalaženjem alternativnih mogućnosti zaposlenja, odnosno, dodatnih izvora prihoda za ruralnu populaciju. Poljoprivredno-prerađivački sektor samo u manjem obimu može da "posluži“ za ovu svrhu, pošto stvaranje ekonomski vitalnih poljoprivrednih gazdinstava znači, pored intenziviranja proizvodnje, $\mathrm{i}$ njihovo ukrupnjavanje, a samim tim i smanjenje broja zaposlenih u agraru. Iz tog razloga, alternativni izvori prihoda moraju se tražiti u razvoju nepoljoprivrednih aktivnosti, koje mogu biti u većoj ili manjoj meri vezane za primarni sektor, dominantan $\mathrm{u}$ ruralnim područjima RS. U kontekstu ruralnog razvoja, čini se da bi samo sveobuhvatni pristup na nacionalnom nivou, koji bi podrazumevao niz koordiniranih mera - počev od demografske politike, preko politike obrazovanja, zdravstvene zaštite, razvoja infrastrukture, agrarne i poreske politike i slično mogao da dovede do značajnih pomaka u nivou ruralne razvijenosti. Drugim rečima, integralna politika ruralnog razvoja podrazumeva dugoročni pristup sa širokim spektrom državnih intervencija, što znači da je za značajnije pomake $u$ ruralnom razvoju potrebno više i vremena i sredstava $\mathrm{u}$ odnosu na performanse IPARD-2 fonda.

\section{ZAKLJUČAK}

Približavanje Republike Srbije Evropskoj uniji predstavlja veliki izazov za celokupan društvenoekonomski sistem, pa ni sektor ruralne ekonomije ne predstavlja izuzetak. Ruralna ekonomija, kao i poljoprivreda imaju relativan značaj za ukupnu privredu RS, što dodatno povećava interes za ovaj sektor $\mathrm{u}$ pretpristupnom periodu. S tim $\mathrm{u}$ vezi, doprinos istraživanja, orijentisan na razvojne probleme ruralnih sredina i IPARD fondove kao jedan od načina za prevazilaženje njihovog ekonomskog zaostajanja, najveći značaj ima u identifikovanju relativno skromnih mogućnosti pretpristupne pomoći EU. Takođe, ukazano je i na ključnu ulogu države u povećanju efektivnosti i efikasnosti korišćenja raspoloživih sredstava i uspostavljanju ekonomske vitalnosti ruralnih područja.

Postavljene hipoteze ne podržavaju uobičajen način razmišljanja o pretpristupnim fondovima, te njihovo testiranje daje drugačiji pristup problemu, $\mathrm{u}$ odnosu na većinu istraživanja iz ove oblasti. Hipoteze su u najvećoj meri potvrđene, pošto je jasno naznačeno da modernizacija poljoprivrede i povećanje kvaliteta života ruralne populacije ne moraju biti jednoznačno uslovljeni procesi.

Međutim, prisutna su i određena istraživačka ograničenja, koja proističu iz metodoloških poteškoća determinisanja uticaja finansijske podrške na razvojne procese. Društveno-ekonomski razvoj predstavlja dugoročan proces zasnovan na adekvatno formulisanoj politici, čiji rezultati nisu jasno vidljivi u kraćem vremenskom intervalu.

Praktičan doprinos istraživanja se ogleda $u$ demonstriranju značaja razvojne politike zasnovane na teritorijalnom principu uz uvažavanje lokalnih specifičnosti, kao i potreba ruralne populacije. Ovo može biti korisno, kako kreatorima agrarne i ruralne politike, tako i akademskoj javnosti koja se interesuje za navedenu problematiku.

U okviru analiza u budućim radovima sagledaće se pozicija ruralnih područja RS u odnosu na zemlje EU, kako bi se detaljnije elaborirale razvojne mogućnosti ovih područja, ali i segmenti u kojima bi bilo opravdano alocirati IPARD fondove.

\section{ENDNOTE}

1 Republika Srbija nema zvaničnu statističku definiciju ruralnih područja, odnosno, prema metodologiji popisa iz 1981, 1991, 2002. i 2011, stanovništvo deli na gradsko i ostalo, koje podrazumeva ruralno stanovništvo.

2 Između poslednja dva popisa 2002. i 2011, ruralna populacija se smanjila za 311.000 stanovnika, što iznosi 10,9\%, što je znatno više u odnosu na smanjenje gradskog stanovništva od $4,15 \%$.

3 Ruralna područja RS biće razmatrana na osnovu četiri definisana statistička regiona na nivou Nomenklature 
statističkih teritorijalnih jedinica (NSTJ 2): Autonomna pokrajina Vojvodina, Beogradski region, Šumadija i Zapadna Srbija i Južna i Istočna Srbija. Ovakva podela, usvojena 2010, relativo dobro oslikava heterogenost ruralnih područja RS.

4 RS u 2015. nije koristila sredstva IPARD fonda, pa je verovatno da će se predviđena sredstva iz ove godine preneti na 2016.

5 Podaci se ne odnose na 2013.

\section{ZAHVALNICA}

Ovaj rad je deo Projekta osnovnih istraživanja (br. III 46006), koji finansira Ministarstvo prosvete, nauke i tehnološkog razvoja Republike Srbije.

\section{REFERENCE}

Bogdanov, N. (2007). Mala ruralna domaćinstva u Srbiji i ruralna nepoljoprivredna ekonomija. Beograd, Republika Srbija: UNDP.

Bogdanov, N. (2015). Ruralni razvoj i ruralna politika. Beograd, Republika Srbija: Poljoprivredni fakultet.

Bogdanov, N. i Babović, M. (2014). Radna snaga i aktionosti poljoprivrednih gazdinstva. Beograd, Republika Srbija: Republički zavod za statistiku.

Cvijanović, D., Subić, J. i Paraušić, V. (2014). Poljoprioredna gazdinstva prema ekonomskoj veličini $i$ tipu proizvodnje $u$ Republici Srbiji. Beograd, Republika Srbija: Republički zavod za statistiku.

Čalić, M. Ž. (2004). Socijalna istorija Srbije, Beograd, Republika Srbija: Klio.

European Commission. (2013). Rural Development in the EU. Report 2013. Retrieved March 10, 2016, from http://ec.europa. eu/agriculture/statistics/rural-development/2013/full-text_ en.pdf

European Commission. (2014a). Instrument for Pre-accession Assistance (IPA II). Indicative strategy paper for Serbia 20142020. Retrieved March 10, 2016, from http://ec.europa.eu/ enlargement/pdf/key_documents/2014/20140919-csp-serbia. pdf

European Commission. (2014b). Serbia 2014 progress report. Retrieved March 10, 2016, from http://ec.europa.eu/ enlargement/pdf/key_documents/2014/20140108-serbiaprogress-report_en.pdf
European Commission. (2015). Serbia 2015 report. Retrieved March 17, 2016, from http://ec.europa.eu/enlargement/pdf/ key_documents/2015/20151110_report_serbia.pdf

Gajić, M., \& Zekić, S. (2013). Development characteristics of agricultural sector in Serbia. In D. Škorić, D. Tomic \& V. Popovic (Eds), Agri-food Sector in Serbia - state and Challenges (pp. 73-90). Belgrade, Republic of Serbia: Serbian Association of Agricultural Economists and Serbian Academy of Science and Art - Board for Village.

Hall, D. (2004). Rural Tourism Development in Southeastern Europe: Transition and the Search for Sustainability. International Journal of Tourism Research, 6(3), 165-176. doi: $10.1002 /$ jtr.482

Komazec, Lj., \& Aleksic, M. (2015). Organic agricultural production in the function of reducing rural poverty - The example of Velebit village in the A. P. of Vojvodina. Economic Horizons, 17(2), 151-159. doi: 10.5937/ekonhor1502155K

Lovre, K. (2013). Policy of Support to Agriculture and Rural Development. In D. Skorić, D. Tomić \& V. Popović (Eds), Agri-food Sector in Serbia - state and Challenges (pp. 233258). Belgrade, Republic of Serbia: Serbian Association of Agricultural Economists and Serbian Academy of Science and Art - Board for Village.

Matkovski, B. i Kleut, Ž. (2014). Integracioni procesi i politika ruralnog razvoja u funkciji konkurentnosti i ekonomske efikasnosti agroprivrede Srbije. Rad prezentovan na naučnom skupu: Strategijski menadžment i sistemi podrške odlučivanju u strategijskom menadžmentu, Subotica, Republika Srbija.

Ministarstvo poljoprivrede i zaštite životne sredine Republike Srbije (MPZŽS RS). (2014). Republika Srbija IPARD program za 2014-2020. godinu. Preuzeto 17.03.2016. sa http://www. mpzzs.gov.rs/wp-content/uploads/datoteke/korisna_ dokumenta/Serbia_IPARD_II_Program_finalni_prevodKorigovano_20_04_2015.pdf

Ristic, L. (2013). Strategic management of sustainable rural development in the Republic of Serbia. Economic Horizons, 15(3), 233-248. doi:10.5937/ekonhor1303229R

Republički zavod za statistiku. (2011). Popis stanovništva u Republici Srbiji u 2011. godini. Preuzeto 17.03.2016. sa www. stat.gov.rs.

Republički zavod za statistiku. (2012). Popis poljoprivrede u Republici Srbiji u 2012. godini. Preuzeto 17.03.2016. sa www. stat.gov.rs.

Sarudi, C., Szakaly, Z., Mathe, A., \& Szente, V. (2003). The Role of Organic Agriculture in Rural Development. Agriculturae Conspectus Scientificus, 68(3), 197-202. 
Zekić, S., \& Matkovski, B. (2014). New CAP reform and Serbian agriculture. In D. Cvijanović, J. Subić \& A. J. Vasile (Eds.), Sustainable agriculture and rural development in terms of the Republic of Serbia strategic goals realization within the Danube region - rural development and (un)limited resources (pp. 10951110). Belgrade, Republic of Serbia: Institute for Agricultural Economics.

Zekić, S. i Matkovski, B. (2015). Razvojne mogućnosti ruralnih područja Srbije. Zbornik Matice Srpske za društvene nauke,
$66(4), 757-771$.

Zekić, S., Gajić, M., \& Matkovski, B. (2013). Serbian agriculture in the regional and European integratons. In D. Tomić, M. Ševarlić, K. Lovre \& S. Zekić (Eds.), Challenges for the Global Agricultural Trade Regime After Doha (pp. 369-376). Belgrade, Republic of Serbia: Serbian Association of Agricultural Economists, Faculty of Economics in Subotica, University of Novi Sad.

Primljeno 5. aprila 2016, nakon revizije, prihvaćeno za publikovanje 22. avgusta 2016. Elektronska verzija objavljena 26. avgusta 2016.

Stanislav Zekić je vanredni profesor na Ekonomskom fakultetu u Subotici Univerziteta u Novom Sadu, uža naučna oblast Agroekonomija. Autor je i koautor većeg broja radova iz oblasti agrarne ekonomije i ruralnog razvoja.

Bojan Matkovski je asistent na Ekonomskom fakultetu u Subotici Univerziteta u Novom Sadu. Student je doktorskih akademskih studija, oblast agrarne ekonomije.

Žana Kleut je saradnik u nastavi na Ekonomskom fakultetu u Subotici Univerziteta u Novom Sadu. Student je doktorskih akademskih studija, oblast agrarne ekonomije. 


\title{
IPARD FUNDS IN THE FUNCTION OF THE DEVELOPMENT OF THE RURAL AREAS OF THE REPUBLIC OF SERBIA
}

\author{
Stanislav Zekic, Bojan Matkovski and Zana Kleut \\ Faculty of Economics, University of Novi Sad, Subotica, The Republic of Serbia
}

By acquiring the conditions for the usage of the pre-accession funds of the European Union, concretely the instrument for rural development (Instrument for Pre-accession Assistance in Rural Development - IPARD), The Republic of Serbia (RS) will have a chance to improve the position of its agricultural farms and the conditions of its rural areas. Agriculture is specifically important for the economy in RS, and the rural population makes up almost one-half of the population, which additionally enlarges an interest in these funds. In addition, the objective of the research is to identify the effects of the usage of the IPARD funds on the development of the rural areas, respectively the socio-economic progress of the rural population. A qualitative descriptive analysis on the basis of the empirical data was used. The basic conclusions are that, thus, structured funds will have a limited impact on the reduction in the development inequalities and the achievement of the parity living conditions between the rural and the urban areas. Namely, the dominant focus of the IPARD funds on the investments in agricultural farms and enterprises, and not in rural households, limits the level of their impact on the rural development in RS.

Keywords: rural development, IPARD funds, agriculture, the Republic of Serbia, the European Union 